\title{
Penentuan Cepat Toksisitas Logam Perak Menggunakan Bioluminesen Bakteri Laut Aliivibrio fischeri, Beijerinck, 1889 (Gammaproteobacteria: Vibrionaceae)
}

\author{
Dedi Futra ${ }^{*}$, Lee Yook Heng² dan Asmat Ahmad² \\ IProgram Studi Pendidikan Kimia, Universitas Riau \\ Kampus Binawidya KM 12,5, Pekanbaru, Riau 28293 Indonesia \\ 2Fakulti Sains dan Teknologi, Universiti Kebangsaan Malaysia \\ Bangi, Selangor, 43600 Malaysia \\ Email: dedifutra@lecturer.unri.ac.id
}

\begin{abstract}
Rapid Determination of Silver Metal Toxicity Using Bioluminescent Marine Bacteria Aliivirbio fischeri Beijerinck, 1889 (Gammaproteobacteria: Vibrionaceae)
\end{abstract}

Rapid determination of toxicity based on changes in the bioluminescent signal of marine bacterium Aliivibrio fischeri (A. fischeri) to evaluate toxicity of Ag(I) has been successfully developed. Assessment of toxicity was designed using inhibition of bioluminescent signal from A. fischeri bacteria, which was exposed with toxic material of $\mathrm{Ag}(\mathrm{l})$. This metal ion was utilized as a model of toxic material to evaluate the effects of cytotoxicity on bacteria cell. Measurement of bioluminescent were taken based on differences in bacterial cell signals before and after exposure to Ag(I) ion at an emission wavelength of $488 \pm 2 \mathrm{~nm}$. The concentration of bacterial cell was used to assess the toxicity of Ag(I) at optical density (OD600 nm) of 0.78 Abs. The results found that the linear response of Ag toxicity was in the range of $0.05-10 \mathrm{mg} / \mathrm{L}$, with $\mathrm{EC}_{50 \%}$ of $8.42 \mathrm{mg} / \mathrm{L}$ for 4 minutes. The repeatability value within the relative standard deviation (RSD) was $2.5-4.7 \%(n=8)$. The results demonstrated that the marine bacteria of A. fischeri have good potential to evaluate toxicity of toxic material in environmental samples.

Keywords: Toxicity, Ag(I) metal, Bioluminescent, bioassay testing, Aliivibrio fischeri,

\begin{abstract}
Abstrak
Penentuan cepat toksisitas berdasarkan perubahan sinyal bioluminesen bakteri laut Aliivibrio fischeri (A. fischeri) untuk mengevaluasi toksisitas logam perak (Ag(I)) telah sukses dikembangkan. Penilaian toksisitas didesain berdasarkan penghambatan sinyal bioluminesen bakteri A. fischeri oleh bahan toksik. Ion logam Ag(I) digunakan sebagai model bahan toksik untuk menilai efek sitotiksisitas pada sel bakteri. Pengukuran bioluminesen diambil berdasarkan perbedaan sinyal sel bakteri sebelum dan sesudah diekspos pada ion logam Ag(I) pada panjang gelombang emisi $488 \pm 2 \mathrm{~nm}$. Konsentrasi sel bakteri yang digunakan untuk menilai toksisitas $\mathrm{Ag}(\mathrm{l})$ pada optikal densitas 600 (OD $600 \mathrm{~nm})=0.78$ Abs. Hasil kajian ditemukan bahwa respons linear toksisitas Ag(I) pada rentang 0.05$10 \mathrm{mg} / \mathrm{L}$, dengan nilai EC $50 \%$ sebesar $8.42 \mathrm{mg} / \mathrm{L}$ pada waktu respons 4 menit dan nilai repeatibilitas toksisitas diperoleh sebesar 2.5-4.7 \% RSD (relatif standar deviasi, n=8). Hasil ini menunjukkan bahwa bakteri laut $A$. fischeri memiliki potensi yang baik untuk menilai toksisitas bahan toksik dalam sampel lingkungan.
\end{abstract}

Kata Kunci: Toksisitas, logam Ag(I), bioluminesen, pengujian bioasai, Aliivibrio fischeri,

\section{PENDAHULUAN}

Kandungan perak dalam lingkungan telah mengalami pening-katan dari hari ke hari, hal ini sesuai dengan peningkatan penggunaan perak dalam bidang industri, kedokteran dan teknologi. Logam perak sering digunakan dalam pengobatan karena 
memiliki aktivitas antimikroba yang dihasilkan dari sifat kimiawi dalam bentuk ionisasi, Ag(I) (Franci et al., 2015). Misalnya, senyawa perak digunakan dalam perawatan gigi dan farmasi (Bondarenko et al., 2013: Franci et al., 2015). Selain itu, logam perak memiliki potensi untuk dijadikan logam yang sangat murni dan digunakan dalam perangkat alat elektronik. Secara luas $\mathrm{Ag}(\mathrm{I})$ digunakan dalam industri fotografi dan pencitraan (Li et al., 2014). Dengan mempertimbangkan penggunaan logam perak yang luas dalam bindan industri, ini menyebabkan pem-buangan limbah yang mengandung logam perak ke lingkungan juga meningkat. Hal ini dapat menyebabkan organisme akuatik terkontaminasi oleh logam perak. Toksisitas perak terhadap organisme akuatik tergantung pada bentuk peraknya. Logam perak dalam bentuk ion sangat beracun terhadap berbagai organisme akuatik karena sifat kimiawi logam perak terionisasi dalam lingkungan akuatik. Sedangkan bentuk logam perak selain perak ionik secara signifikan sedikit toksik terhadap organisme akuatik (Li et al., 2014: Bondarenko et al., 2014). Dengan berpa-tokan pada efek negatif yang ditimbulkan oleh ion logam perak terhadap organisme, maka penentuan toksisitas ion logam perak dalam sampel lingkungan sangat penting untuk dilakukan.

Beberapa teknik analitik telah digunakan untuk menentukan logam ion Ag(I) dalam sampel lingkungan seperti spektroskopi serapan atom (Ghaedi et al., 2009), ekstraksi fase pada kolorimetrik (Mashhadizadeh dan Karami, 2011: Yang et al., 2009), spektrometri massa plasma digambungkan secara indukti (ICP-MS) (Laborda et al., 2011) dan spektrometri emisi optik digabungkan plasma secara indukti (ICP-OES) (Mashhadizadeh dan Karami, 2011). Teknik pengujian ini, biasanya digunakan untuk mengukur ion logam di laboratorium, tidak sesuai untuk evaluasi dan pemantauan secara in situ, dan memerlukan keahlian untuk mengoperasikannya.

Kekinian, penentuan toksisitas logam berat $\mathrm{Ag}(\mathrm{I})$ dalam sampel lingkungan popular menggunakan pengujian secara bioasai yaitu menggunakan organisme hidup untuk menentukan ketoksikan suatu bahan toksik $(\mathrm{Ag}(\mathrm{I}))$. Kelebihan metode ini adalah dapat membedakan antara bahan kimia yang berpotensi berbahaya dan tidak berbahaya terhadap mikro-organisme dalam waktu respon yang cepat. Bioasai toksisitas memanfaatkan Mikrotokks / Lumistoks komersial yang mengandung kultur keringbeku bakteri Vibrio fischeri untuk menilai toksisitas logam berat dari sampel lingkungan (Hsieh et al., 2004; Cukurluoglu dan Muezzinoglu, 2013). Bioasai Mikrotoks sangat efektif menentukan toksisitas logam dalam sampel lingkungan, walau bagaimanapun metode Mikrotoks ini memiliki sensitivitas rendah, waktu respon yang lama (15 menit hingga Jam). Hsieh et al., (2004) telah mengembangkan pengujian ketoksikan logam $\mathrm{Cu}, \mathrm{Pb}, \mathrm{Sb}, \mathrm{Ag}, \mathrm{Ti}, \mathrm{Zn}, \mathrm{Be}, \mathrm{Hg}$ dan $\mathrm{Ni}$ dalam sampel lingkungan menggunakan pereaksi Mikrotoks-Vibrio fischeri. Kajian toksisitas Mikrotoks ini menunjukan waktu respon yang lama 48 jam.

Pengujian toksistas bahan beracun lainnya telah dilaporkan menggunakan bioasai berbasis organisme hidup seperti bakteri Escherichia coli dimodifikasi dengan pbenzoquinone untuk menentukan ketoksikan logam Ag(I) (Yu et al., 2013), remis Perna viridis untuk menilai ketoksikan logam Ag (I) (Vijayavel, 2010), ikan Capoeta fusca untuk memantau ketoksian logam $\mathrm{Hg}(\mathrm{l})$ dan $\mathrm{Ag}(\mathrm{I})$ (Mansouri et al., 2011), algae Ulva pertusa untuk menganalisis ketoksikan logam Ag(I), As (I), Cd(II), Co(II), Cr(VI) dan Cu(II) (Han et al., 2009), copepod laut Acartia tonsa untuk menilai ketokiksian Ag(I) (Pedrosa et al., 2007) dan Pseudokirchneriella subcapitata dan Chlamydomonas rein-hardtii untuk mengevaluasi ketoksikan Ag(I) (Hiriart-Baer et al., 2006). Bioasai toksisitas ini telah berhasil menentukan ketoksikan dalam sampel lingkungan, tetapi waktu inkubasi antara organisme dan bahan toksik $\mathrm{Ag}(\mathrm{I})$ memerlukan waktu respons yang lama 6-96 jam. Tujuan penelitian ini adalah untuk menentukan toksisitas ion logam perak menggunakan bakteri laut Aliivibrio fischeri. Alasan pemilihan bakteri ini sebagai bahan biologi untuk mengevaluasi toksisitas logam Ag(I) kerana sel bakteri ini secara alami memiliki cahaya bioluminesen yang stabil.

\section{MATERI DAN METODE}

Bahan kimia yang digunakan dalam penelitian ini adalah kualitas analisis tanpa 
dilakukan pemurnian dan air akuades yang dimurni [(deionized water $\left(\mathrm{dH}_{2} \mathrm{O}\right)$ ] digunakan untuk persiapan larutan. Larutan stok $\mathrm{Ag}^{+} 500$ $\mathrm{mg} / \mathrm{L}$ disiapkan dengan melarutkan garam nitrat (BDH, Radnor, USA) dalam $\mathrm{dH}_{2} \mathrm{O}$. Larutan stok etanol $70 \%$ disediakan dengan mencairkan etanol 96 \% (Merk, Jerman) dengan air murni $\mathrm{dH}_{2} \mathrm{O}$. Larutan stok nutrient agar (NA) $28 \mathrm{~g} / \mathrm{L}$ (Scharlau, Spanyol), dan nutrient broth (NB) $13 \mathrm{~g} / \mathrm{L}$ (Oxoid, UK) yang masing-masing mengandung $3 \% \mathrm{NaCl}$ (Sigma, US) disiapkan dengan pelarut $\mathrm{dH}_{2} \mathrm{O}$ dan disterilkan dengan cara autoklap pada suhu $121^{\circ} \mathrm{C}$, tekanan 5 psi. selama 20 menit, serta larutan penyangga Hepes. Stok kultur bakteri A. fischeri dalam $15 \%$ gliserol diperoleh dari Laboratorium Mikrobiologi, Universiti Kebangsaan Malaysia) dan dijaga pada suhu -80 oC. Sementara itu, peralatan yang digunakan seperti, laminar air flow cabinet (Gelman Sciences. LTD), cawan petri, jarum inokulum, mikro pipet, sentrifugasi, tabung sentrifugasi $(10 \mathrm{~mL})$, Erlenmeyer $(250 \mathrm{~mL})$, inkubator bakteri, shaker, autoklap, Spektrofometer dan spektrofluorimeter, Perkin Elmar (Waltham, USA).

Penghasilan kultur bakteri sel A fischeri mengikut metode yang dimodifikasi dari Futra et al., (2014). Secara ringkasnya; sebanyak 20 $\mathrm{mL}$ stok bakteri A. fischeri dalam 15\% gliserol ditumbuhkan dalam $20 \mathrm{~mL}$ NA pada suhu ruang selama 16 jam. Koloni tunggal bakteri ini diisolasi dan ditumbuhkan dalam $4 \mathrm{~mL}$ nutrient broth segar yang mengandung $\mathrm{NaCl}$ dalam keadaan di-shaker dengan kecepatan 250 rpm pada suhu ruang $\left(27^{\circ} \mathrm{C}\right)$ selama 16 jam, hasil kultur ini digunakan sebagai stok prekultur. Sebanyak $0.5 \mathrm{~mL}$ stok pre-kultur selanjutnya ditumbuhkan dalam nutrient broth segar yang mengandung $\mathrm{NaCl}$ selama 6 jam pada kondisi yang sama. Sel bakteri diambil dengan cara sentrifugasi dengan kecepatan $1000 \mathrm{rpm}$ pada suhu $4^{\circ} \mathrm{C}$ selama 10 menit dan sel bakteri disuspensi dalam $10 \mathrm{~mL}$ larutan penyangga Hepes $5 \mathrm{mM}$, pada $\mathrm{pH} 7$.

Bakteri luat $A$. fischeri ditumbuhkan dalam nutrient broth yang mengandung $\mathrm{NaCl}$ selama 24 jam. Penentuan konsentrasi sel bakteri diukur pada OD $600 \mathrm{~nm}$ (Abs) dengan cara kultur bakteri diambil sebanyak dua $\mathrm{mL}$ setiap periode waktu 1 jam selama 24 jam pertumbuhan. Konsentrasi sel bakteri ditentukan dengan alat spektrofotometer (SpectronicR 20 genesys ${ }^{T M}$ ).

Efek konsenstrasi sel bakteri dianalisis dengan menggunakan beberapa seri konsentrasi sel $A$. fischeri yaitu pada OD 600 $\mathrm{nm} 0.15,0.450 .78,1.10,1.22$ Abs. Sel bakteri ini disuspensi dalam larutan $10 \mathrm{~mL}$ panyangga Hepes 5 mM pada pH 7 dan diukur response bioluminesennya dengan alat spektrofluorimeter.

Studi efek waktu respons dilakukan kepada sel bakteri $A$. fischeri pada umur pertumbuhan 6 jam atau OD $600 \mathrm{~nm} 0.78$ Abs. Analisis toksisitas dijalankan pada sel bakteri yang telah disuspensi dalam larutan penyangga Hepes. Konsentrasi bahan toksik $\mathrm{Ag}(\mathrm{I})$ digunakan untuk melihat inhibisi sel bakteri A. fischeri ialah $7 \mathrm{mg} / \mathrm{L}$ dan $10 \mathrm{mg} / \mathrm{L}$. Kontrol digunakan sebagai pembanding respons bioluminesen ialah $\mathrm{dH}_{2} \mathrm{O}$. Respons toksisitas bioasai diukur setiap interval waktu inkubasi $0,0.5,1.0,2.0,4.0,6.0,8.0,10.0,12.0$, 15.0 menit, dengan pengulangan tiga kali.

Sebanyak $1.5 \mathrm{~mL}$ kultur bakter A. fischeri dalam suspensi larutan penyanggaHepes dimasukan ke dalam quarzts $(2 \mathrm{~mL})$ spektrofluorimeteri. Respons toksisitas diambil pada penambahan $40 \mu \mathrm{L}$ air murni $\mathrm{dH}_{2} \mathrm{O}$ sebagai kontrol dan volume yang sama ditambahkan ke atas suspensi sel A. fischeri yang mengandung bahan toksik $A g(I)$. Seri konsentrasi bahan toksik Ag(I) yang ditambahkan pada suspensi sel bakteri $A$. fischeri sebesar 0.01-70 mg/L. Sinyal intensitas bioluminesen bakteri $A$. fischeri diukur pada panjang gelombang eksitasi dan emisi masing-masing $285 \pm 2 \mathrm{~nm}$ dan $488 \pm 2 \mathrm{~nm}$. Penilaian inhibisi sel $A$. fischeri dianalisis berdasarkan persamaan persentase relatif luminesen unit (\% RLU) ditunjukkan seperti pada Persamaan 1 (Futra et al., 2014). Semua eksperimen dijalankan minimal tiga kali ulangan pada suhu ruang $(25 \pm 2)^{\circ} \mathrm{C}$. Waktu respons ketoksikan bakteri $A$. fischeri diukur pada waktu inkubasi dengan bahan toksik selama 4 menit. Dimana A adalah intensitas bioluminesen mangandung bahan toksik dan $B$ adalah intensitas bioluminesen tanpa bahan toksik.

$$
\% R L U=\frac{A}{B} \times 100 \%
$$


Pengujian repeatabilitas dilakukan kepada sel bakteri $A$. fischeri dengan menggunakan delapan (8) konsentrasi sama sel bakteri pada OD $600 \mathrm{~nm}=0.78$ Abs yang telah disuspensi dalam larutan penyangga Hepes. Konsentrasi bahan toksik Ag(I) yang diujikan kepada sel bakteri untuk melihat kemampuan inhibisi bahan toksik tersebut adalah $2 \mathrm{mg} / \mathrm{L}$ dan $5 \mathrm{mg} / \mathrm{L}$. Pengukuran dilakukan pada suhu ruang $\left(25 \pm 2{ }^{\circ} \mathrm{C}\right)$.

\section{HASIL DAN PEMBAHASAN}

Karakteristik respons biolumi-nesen bioasai toksisitas bakteri laut $A$. fischeri sebelum dan sesudah diekspos pada bahan toksik dan spectrum emisi dari bakteri Escherichia coli dan A. fishceri diautoklaf ditunjukkan pada Gambar 1. Dalam keadaan tanpa bahan toksik diberikan pada pada suspensi sel bakteri $A$. fischeri ditemukan intensitas luminesen sangat tinggi pada puncak $488 \pm 2 \mathrm{~nm}$. Respons intensitas bioluminesen diperoleh menurun setelah diinkubasi selama 4 menit dengan ion $\mathrm{Ag}$ (I) 20 $\mathrm{mg} / \mathrm{L}$. Ini dikontribusi oleh adanya reaksi antara bahan toksik dengan gugus fungsi asam karboksilat $(-\mathrm{COOH})$ dalam bakteri sel, dengan demikian, menghambat proses metabolisme sel (Futra et al., 2014). Tidak ada sinyal luminesen ditemukan pada bakteri Escherichia coli dan A. fisheri autoklaf, untuk sel bakteri A. fischeri autoklaf sudah mengalami pensterilan dan penghancuran sel.

Profil pertumbuhan sel bakteri A. fischeri dalam medium cair yang diukur selama 24 jam dilukiskan pada Gambar 2. Pada awal inkubasi sel bakteri diperoleh pertumbuhan lambat atau fase pertumbuhan awal untuk selama 0-3 jam. Hal ini disebabkan sel bakteri mengalami adaptasi dengan lingkungannya yang baru dan sel bakteri mulai menggandakan selnya (Prescott et al., 2002). Selanjutnya pertumbuhan bakteri dilanjutkan pada waktu 3-9 jam diperoleh fase pertumbuhan cepat atau fase pertumbuhan eksponen. Pertumbuhan cepat ini disumbangkan oleh aktivitas matebolisme sel untuk menghasilkan protein, DNA dan RNA berjalan dengan cepat dan progresif, sehingga kemampuan mikroba untuk menggandakan selnya berjalan dengan cepat karena didukung oleh ketersediaan sumber nutrisi untuk pertumbuhan sel yang mencukupi (McCall et al., 2001). Sementara itu, pertumbuhan bakteri terjadi secara statik atau fase pertumbuhan stationari untuk waktu pertumbuhan 9 - 24 jam. Ini dikontribusi oleh jumlah sel yang hidup sama dengan jumlah sel yang mati, karena terjadinya persaingan sel mikroba untuk mendapatkan sumber nutrisi yang tidak mencukupi untuk pertumbuhan sel (Prescott et al., 2001). Untuk penelitian selanjutnya digunakan fase pertumbuhan eksponen untuk menilai toksisitas bahan toksik. Perubahan respons intensitas bioluminesen terhadap berbagai konsentrasi sel bakteri $A$ fischeri diilustrasikan pada Gambar 3. Sinyal intensitas bioluminesen diperoleh meningkat dengan penambahan sel mikroba pada konsentrasi 0.15-0.78 abs, ini dikaitkan dengan jumlah sel yang meningkat sehingga menghasilkan sinyal bioluminesen yang tinggi. Di samping itu, ketersediaan dan penyebaran oksigen dalam medium cair untuk pernapasan sel juga mencukupi, sehingga proses metabolisme sel tidak terganggu. Jika konsentrasi sel bakteri ditingkatkan dari 0.78 abs menjadi 1.22 abs diperoleh respons intensitas bioluminesen menurun. Hal ini dihubunkan dengan jumlah sel yang padat yang menyebabkan ketersedian dan penyebaran oksigen untuk pernapasan sel tidak mencukupi sehingga aktivitas reaksi oksidasi dalam sel terganggu (Gil et al., 2000). Di samping itu, konsentrasi sel yang tinggi menyumbang kepada terjadi nya sinyal bioluminesen mengalami quenching, dimana sinyal bioluminesen suatu sel bakteri serap oleh sel bakteri lainnya yang tidak memiliki cahaya pancaran bioluminesen, sehingga cahaya bioluminesen yang dihasilkan tidak optimum (Kim dan Gu, 2003). Untuk kajian berikutnya konsentrasi sel $A$. fischeri yang digunakan pada konsentrasi 0.78 abs.

Sitotoksisitas bakteri A. fischeri yang diekspos dengan bahan toksik Ag(I) pada waktu inkubasi selama 0.5-15.0 menit ditunjukkan pada Gambar 4. Tanpa ion logam $\mathrm{Ag}(\mathrm{I})$ yang ditambahkan pada sel bakteri $A$. fischeri diperoleh respons relatif luminesen stabil tinggi. Apabila sel bakteri dieksposkan dengan bahan toksik dan diinkubasi selama 0.5-4.0 menit ditemukan sinyal relatif 
luminesen menurun secara agresif. Hal ini disumbangkan oleh sudah terjadinya reaksi antara bahan toksik dengan gugus fungsi karboksilat pada sel bakteri. Jika waktu inkubasi dilanjutkan selama 4.0-15.0 menit diperoleh sinyal toksisitas stabil rendah dan tidak terdapat penurunan secara signifikan. Ini dikontribusikan oleh reaksi kompleks gugus fungsi karboksilat sudah sepenuhnya bereaksi dengan bahan toksik $A g(I)$, sehingga pada penambahan waktu inkubasi tidak berpengaruh lagi terhadap respons sitotoksisitas. Untuk kajian selanjutnya digunakan waktu respons 4 menit untuk menilai toksisitas sel A. fischeri (Gambar 4).

Profil persentase toksisitas (A) dan linear range (B) sel bakteri $A$. fischeri terhadap berbagai konsentrasi bahan toksik dilukiskan pada Gambar 5. Apabila tanpa bahan toksik ditambahkan pada sel A. fischeri didapati sinyal persentase toksisitas relatif stabil tinggi. Respons ini dijadikan kontrol atau standar untuk dibandingkan dengan respons yang mengandung bahan toksik. Sinyal persentase bioluminesen yang tinggi tanpa bahan toksik disebabkan oleh belum terjadi reaksi antara bahan toksik $\mathrm{Ag}(\mathrm{I})$ dengan sisi aktif gugus fungsi karboksilat ( $\mathrm{RCOOH}$ ) sel bakteri, dimana karboksilat rantai panjang memiliki kepekaan yang tinggi terhadap bahan toksik (Girotti et al., 2008). Sinyal relatif bioluminesen diperoleh menurun secara drastis dengan keberadaan bahan toksik Ag(I) pada konsentrasi 0.05-10.00 $\mathrm{mg} / \mathrm{L}$. Hal ini disumbangkan telah terjadi reaksi antara bahan toksik Ag(I) dengan bagian aktif gugus fungsi karboksilat. Kompleks yang terbentuk antara gugus fungsi karboksilik dengan kation bahan toksik $\mathrm{Ag}(\mathrm{l})$ akan mengganggu aktivitas metabolisme sel untuk menghasilkan energi bioluminesen, sehingga cahaya pancaran bioluminesen yang

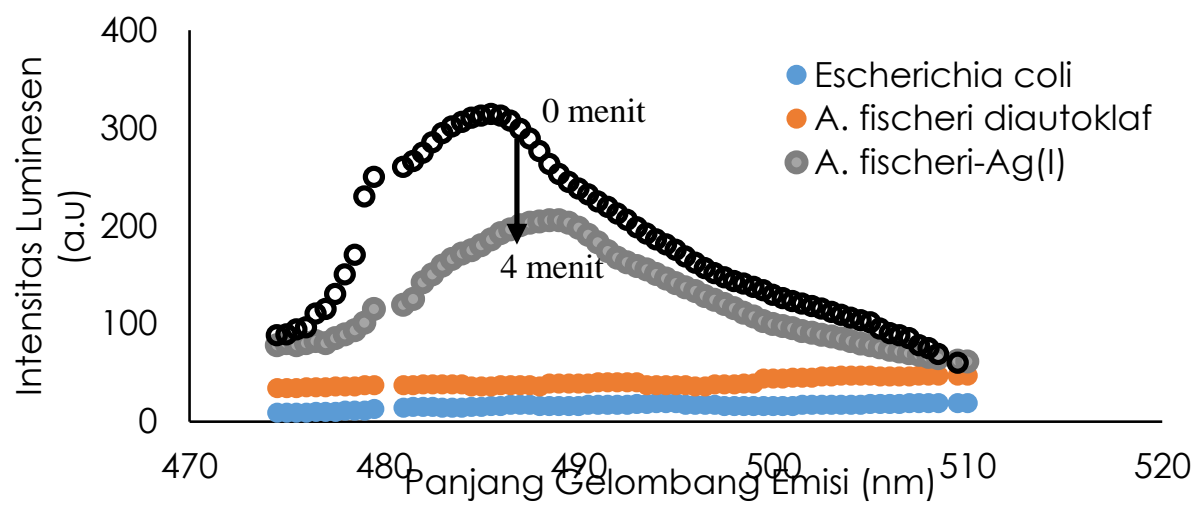

Gambar 1. Respons luminesen toksisitas sel mikroorganise sebelum dan sesudah diberikan bahan toksik $\mathrm{Ag}(\mathrm{I}) 10 \mathrm{mg} / \mathrm{L}$ dan dibandingkan dengan sinyal bioluminesen bakteri Escherichia coli dan A. fischeri diautoklaf

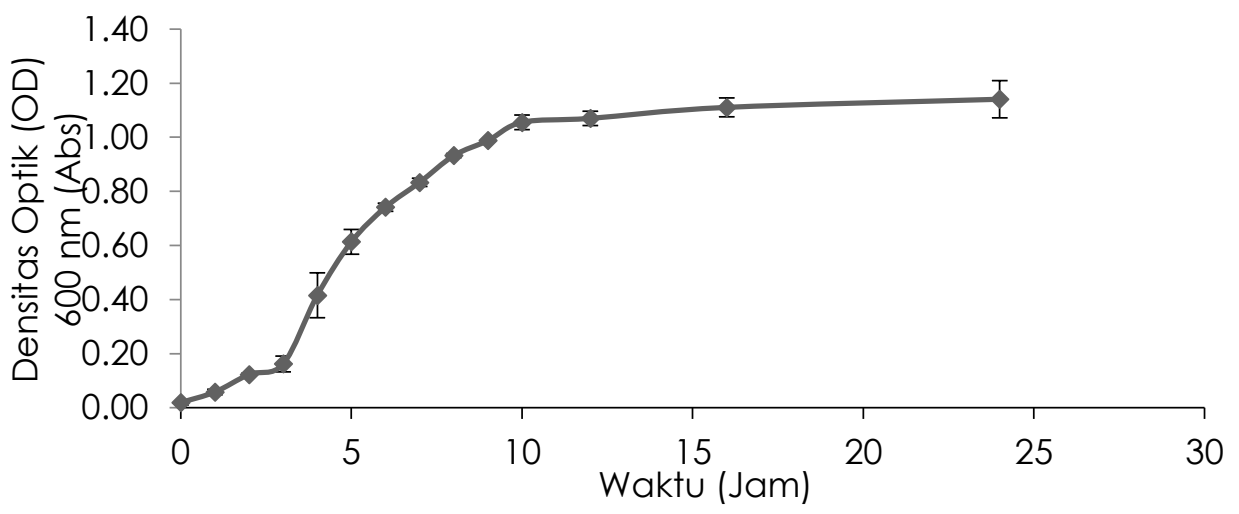

Gambar 2. Profil pertumbuhan bakteri A. fisheri dalam medium cair nutrient broth yang mengandung $\mathrm{NaCl}$ yang diinkubasi pada suhu ruang selama 24 jam. 


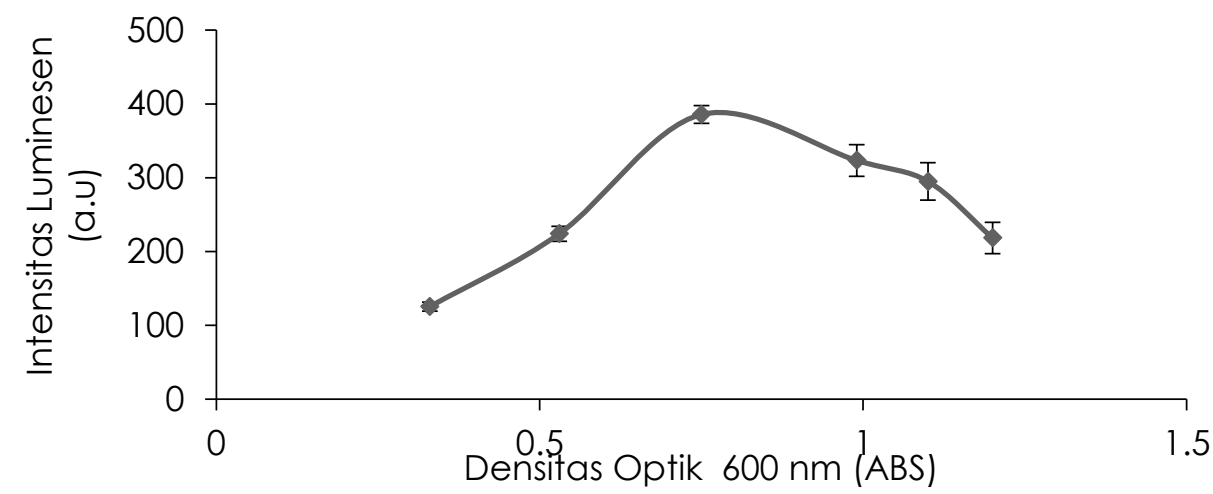

Gambar 3. Respons intenstias bioluminesen bakteri A. fischeri yang diukur pada seri konsentrasi pada OD $600 \mathrm{~nm} 0.15-1.22$ abs.

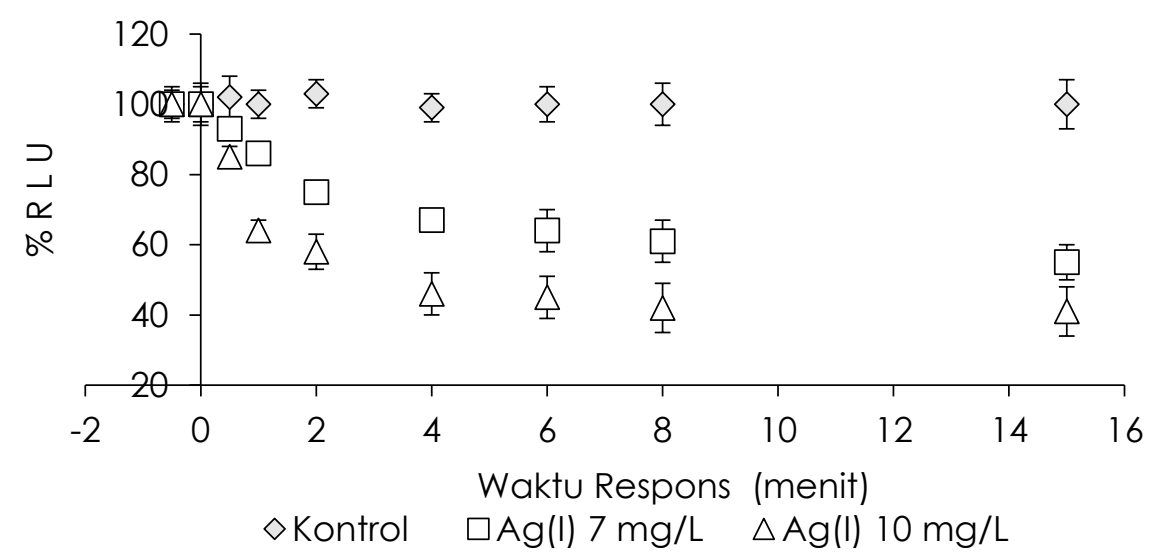

Gambar 4. Respons sitotoksisitas sel bakteri A. fischeri yang dinilai terhadap bahan toksik Ag(I) pada konsentrasi $10 \mathrm{mg} / \mathrm{L}$ dan $30 \mathrm{mg} / \mathrm{L}$ dengan waktu inkubasi pada 0.5-15 menit.

dihasilkan tidak sesuai dengan yang diharapkan (Girotti et al., 2008). Berdasarkan penurunan sinyal relatif bioluminesen sel $A$. fischeri terhadap toksisitas Ag(I), maka diperoleh nilai linear range toksisitas ion $\mathrm{Ag}(\mathrm{l})$ sebesar 0.05-10.00 mg/L, batas pendeteksian (LOD) sebesar $0.031 \mathrm{mg} / \mathrm{L}$ dan persentase nilai efektif konsentrasi (EC 50\%) 8.42 mg/L (Tabel 1).

Berdasarkan data pada Tabel 2, prestasi toksisitas bioasai bakteri laut $A$. fisheri yang dibandingkan dengan beberapa pengujian secara bioasai menggunakan berbagai organisme. Toksisitas bioasai menggunakan bakteri $A$. fischeri menunjukkan prestasi yang lebih baik dalam waktu respons jika dibandingkan dengan bioasai menggunakan bakteri (Yu et al., 2013), ikan (Mansouri et al., 2011), ganggan hijau (Han et al., 2009) dan kerang hijau (Vijayavel 2010). Nilai EC50\% yang hampir sama yang diperoleh dalam penelitian ini dengan hasil yang dilaporkan menggunakan $E$. coli yang dimodifikasi dengan benzoquinone (Yu et al., 2013). Walaubagimanapun, hasil penelitian ini memiliki nilai $\mathrm{EC}_{50 \%}$ lebih tinggi dibandingkan dengan ikan (Mansouri et al., 2011) ganggan hijau (Han et al., 2009) dan kerang hijau (Vijayavel 2010).

Respons toksisitas bioasai dari bakteri A. fischeri untuk memonitor bahan toksik dapat diproduksi berdasarkan nilai relative standar deviasi (RSD, $\mathrm{n}=8$ ) yaitu dalam range 3.2-4.2 \%. Nilai RSD yang baik ini dikontribusikan bahwa bakteri A. fischeri yang memiliki cahaya pancaran luminesen yang stabil, yang dihasilkan secara alami dalam sel bakteri (Girroti et al., 2008). Nilai repeatabilitas yang rendah menunjukkan bioasai memiliki reproduksibilitas yang tinggi untuk digunakan dalam pengujian toksisitas bahan toksik. 


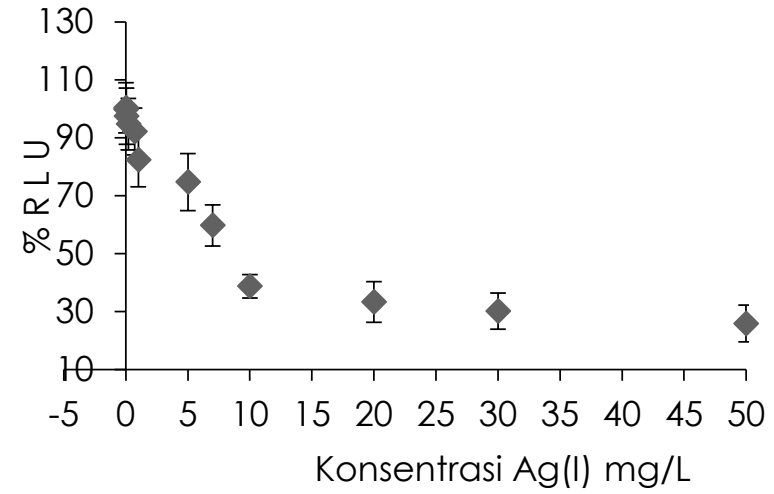

(a)

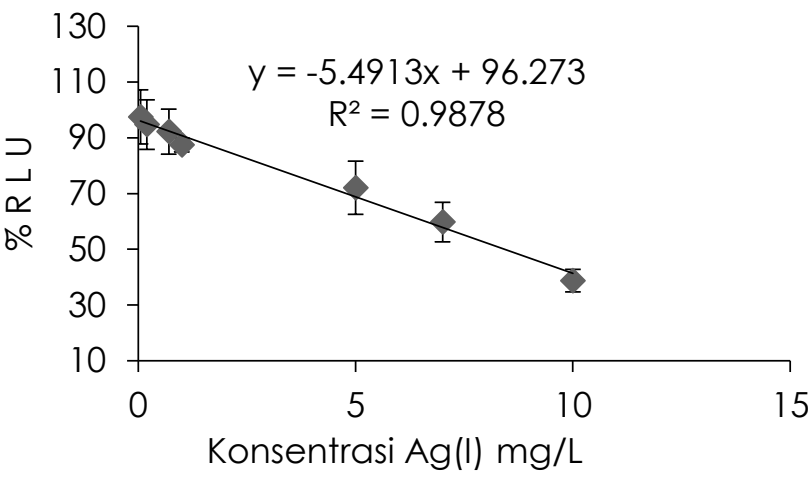

(b)

Gambar 5. Profil respons toksisitas (A) dan linear range (B) yang diperoleh dari berbagai konsentrasi bahan toksik yang ditambahkan pada sel $A$. fischeri.

Tabel 1. Perbandingan prestasi toksisitas bioasai bakteri A fischeri dalam menentukan ketoksikan ion logam Ag(I) dengan beberapa penelitian lain.

\begin{tabular}{lccccc}
\hline \multicolumn{1}{c}{ Bahan biologi } & $\begin{array}{c}\text { Linear range } \\
(\mathrm{mg} / \mathrm{L})\end{array}$ & $\begin{array}{c}\mathrm{LOD} \\
(\mathrm{mg} / \mathrm{L})\end{array}$ & $\begin{array}{c}\mathrm{EC}_{50 \%} \\
(\mathrm{mg} / \mathrm{L})\end{array}$ & $\begin{array}{c}\text { Waktu respon } \\
\text { (menit) }\end{array}$ & Referensi \\
\hline A. fischeri & $0.05-10.00$ & 0.031 & 8.42 & 4 & Penelitian ini \\
Escherichia coli- $\mathrm{p}-$ & - & - & 8.14 & 60 & Yu et al., 2013 \\
benzoquinone & - & - & 0.014 & 1440 & Mansouri et al., 2011 \\
Capoeta fusca & - & - & 0.045 & 5760 & Han et al., 2009 \\
Ulva pertusa & - & - & 3.88 & 5760 & Vijayavel, 2010 \\
Perna viridis & - & & & &
\end{tabular}

\section{KESIMPULAN}

Toksisitas bioasai berdasarkan bakteri laut A fischeri telah sukses dikembangkan untuk mendeteksi ketoksikan bahan toksik $\mathrm{Ag}(\mathrm{I})$. Prestasi analitik menunjukkan nilai linear range yang luas, batas pendeteksian yang kecil, nilai $\mathrm{EC}_{50 \%}$ yang rendah, dan waktu respons yang cepat dalam satuan menit. Di samping itu, toksisitas berdasarkan bakteri $A$. fischeri dapat digunakan untuk menilai ketoksikan dengan nilai reproduksi RSD $<5 \%$ $\mathrm{n}=8$. Untuk itu, toksisitas biasai yang dikembangkan menggunakan bakteri laut $A$. fischeri memiliki pontensi yang baik untuk mengevaluasi toksisitas logam berat dalam sampel lingkungan.

\section{DAFTAR PUSTAKA}

Bondarenko, O., Juganson, K., IVask, A., Kasemets, K., Mortimer, \& M., Kahru, A. 2013. Toxicity of $\mathrm{Ag}, \mathrm{CuO}$ and $\mathrm{ZnO}$ nanoparticles to selected environmentally relevant test organisms and mammalian cells in vitro: a critical review. Arch. Toxicol, 87:1 181-1200. doi: 10.1007/s00204-013-107 9-4

Cukurluoglu, S., \& Muezzinoglu, A. 2013. Assessment of toxicity in waters due to heavy metals derived from atmospheric de-position using Vibrio fischeri. J. Environ. Sci.Health A. 48:57-66. doi: 10.1080/10934 529.2012 .707840

Franci, G., Falanga, A., Galdiero, S., Palomba, L., Rai, M., Morelli, G., \& Galdiero, M. 2015. Silver Nanoparticles as Potential Antibacterial Agents. Molecules, 20: 88568874. doi: 10.3390/molecules20058856

Futra, D., Heng, L.Y., Surif, S., Ahmad, A., \& Ling. T.L. 2014. Microencapsulated Aliivibrio fischeri in Alginate Microspheres for Monitoring Heavy Metal Toxicity in Environmental Waters. Sensors, 14:2324823268. doi: 10.3390/s141223248

Ghaedi, M., Shokrollahi, A., Niknam, K., Niknam, E., Najibi, A., \& Soylak, M. 2009. Cloud point extraction and flame atomic 
absorption spectrometric determination of cadmium (II), lead (II), palladium (II) and silver (I) in environmental samples. J. Hazardous Mate., 168: 1022 -1027. doi: 10.1016/j.jhazmat.2009.02.130

Gil, G.C., Mitchell, R.J., Chang, S.T., \& GU, M.B. 2000. A biosensor for the detection of gas toxicity using a recombinant bioluminescent bacterium. Biosens. Bioelectron., 15: 23-30. doi: 10.1016/S09565663(99)00074-3

Girotti, S., Ferri, E.N., Fumo, M.G. \& Maiolini, E. 2008. Review Monitoring of environmental pollutants by bioluminescent bacteria. Anal. Chim. Acta, 608:2-29. doi: 10.1016/ j.aca.2007.12.008

Han, Y-S., Kumar, A.S., \& Han, T. 2009. Comparison of Metal Toxicity Bioassays Based on Inhibition of Sporulation and Spore Release in Ulva pertusa. J. Toxicol. Environ. Health Sci., 1(1):24-31. doi: 10.1007/BF03216460

Hiriart-Baer, V.P., Fortin, C., Lee, D-Y., \& Campbell, P.G.C. 2006. Toxicity of silver to two freshwater algae, Chlamydomonas reinhardtii and Pseudokirchneriella subcapita-ta, grown under continuous culture conditions: Influence of thiosulphate. Aquat. Toxicol., 78:136-148. doi: 10.1016/j.aquatox.2006.02.027

Hsieh, C.Y., Tsai, M-H., Ryan, D.K., \& Pancorbo, O.C. 2004. Toxicity of the 13 priority pollutant metals to Vibrio fisheri in the Microtox chronic toxicity test. Sci. Total Environ., 320:37-50. doi: 10.1016/S0048-96 97(03)00451-0

Kim, B.C., \& GU, M.B. 2003. A bioluminescent sensor for high throughput toxicity classification. Biosens. Bioelectron., 18:10151021. doi: 10.1016/s0956-5663(02)00220-8

Laborda, F., Jimenez-Lamana, J., Bolea, E., \& Castillo, J.R. 2011 . Selective identification, characterization and determination of dissolved silver(I) and silver nanoparticles based on single particle detection by inductively coupled plasma mass spectrometry. J. Anal. At. Spectrom., 26: 1362-1371. doi: 10.1039/COJA00098A

Li, L., Wu, H., Peijnenburg, W.J.G.M., \& van Gestel, C.A.M. 2014. Both released silver ions and particulate Ag contribute to the toxicity of AgNPs to earthworm Eisenia fetida. Nanotoxicol., 9(6): 792-801. doi: 10.3109/17435390.2014.976851

Mansouri, B., Baramaki, R., \& Ebrahimpo, M. 2011. Acute toxicity bioassay of mercury and silver on Capoeta Toxicol. Ind. Health, 28(5): 393-398. doi: $10.1177 / 0748233711413796$

Mashhadizadeh, M.H., \& Karami. Z. 2011 . Solid phase extraction of trace amounts of $\mathrm{Ag}$, $\mathrm{Cd}, \mathrm{Cu}$, and $\mathrm{Zn}$ in environmental samples using magnetic nanoparticles coated by 3-(trimethoxysilyl)-1 -propantiol and modified with 2-amino-5-mercapto-1,3,4thiadiazole and their determination by ICP-OES. J. Hazard.Mater., 190:1023-1029. doi: 10.1016/j.jhazmat.2011.04.051

McCall, D., Stock, D. \& Achay, P. 2001. Introduction to microbiology. Massachusatts, USA. The Black Science Inc.

Parvez, S., Venkataraman, C., \& Mukherji, S. 2006. A review on advantages of implementing luminescence inhibition test (Vibrio fischeri) for acute toxicity prediction of chemicals. Environ. Int., 32: 265-268. doi: 10.1016/j.envint.2005.08.022

Pedroso, M.S., Pinho, G.L.L., Rodrigues, S.C., \& Bianchini A. 2007. Mechanism of acute silver toxicity in the euryhaline copepod Acartia tonsa. Aquat. Toxicol., 82:173-180. doi: 10.1016/j.aquatox.2007.02.009

Prescott, L.M., Harley, J., \& Klein, J. 2002 Microbiology, fifth Edition. New York. McGraw-Hill Companies

Vijayavel, K. 2010. Water chemistry influences the toxicity of silver to the green-lipped mussel Perna viridis. Environ. Monitor. Assessment, 167:289-295.

Yang, G., Fen, W., Lei, C., Xiao, W., \& Sun, H. 2009. Study on solid phase extraction and graphite furnace atomic absorption spectrometry for the determination of nickel, silver, cobalt, copper, cadmium and lead with $\mathrm{MCl}$ GEL CHP 2OY as sorbent. J. Hazard. Mater., 162; 44-49. doi: 10.1016/j.jhazmat.2008.05.007

Yu, D., Zhai, J., Yong, D., \& Dong, S. 2013. A rapid and sensitive $p$-benzoquinonemediated bioassay for determination of heavy metal toxicity in water. Analyst, 138: 3297-3302. doi: 10.1039/C3AN36907B 